\title{
Amplification of Anthropogenic Pressure Heavily Hampers Natural Ecosystems Regeneration within the Savanization Halo Around Lubumbashi City (Democratic Republic of Congo)
}

\author{
Yannick Useni Sikuzani ${ }^{1 *}$, Héritier Khoji Muteya ${ }^{1}$, Serge Langunu ${ }^{1}$, Alexis Gerardy ${ }^{2}$ and Jan Bogaert ${ }^{2}$ \\ ${ }^{1}$ Ecology, Restoration Ecology and Landscape Unit, Faculty of Agronomic Sciences, University of Lubumbashi, DR Congo \\ ${ }^{2}$ Biodiversity and Landscape Unit, Gembloux Agro-Bio Tech, University of Liège, Belgium
}

Submission: January 28, 2019; Published: February 13, 2019

*Corresponding author: Yannick Useni Sikuzani, Faculty of Agronomic Sciences, Ecology, Restoration Ecology and Landscape Unit, University of Lubumbashi, 1825 Lubumbashi, DR Congo.

\begin{abstract}
Located in the south-east of the Democratic Republic of Congo (DR Congo), Lubumbashi city is surrounded by a belt of savanna, referred to as "savanization halo", where rare miombo woodland patches could be spotted. This study evaluated the impact of anthropogenic activities on changes in the spatio-temporal pattern within that savanization halo between 2002 and 2017. A mapping approach coupled with landscape ecology analysis tools enabled highlighting both the diagnosis of land cover changes and the processes underlying the spatio-temporal dynamics. Results globally attested that the savanization halo was in constant mutation from 2002 to 2017. Importantly, it was apparent that the dissection, fragmentation and attrition of miombo was amplified by the creation and aggregation of savanna and built-up-bare land complex. Wetland attrition was found to be an additional manifestation of natural ecosystem degradation, with the resulting bare soils suggested as being flooded through the creation of waterbody patches. Agricultural and infrastructural development, supported by rapid population growth, no longer allows natural formations (forest and wetland) to recover from disturbances. It is important to reverse the current trend towards complete anthropization within the savanization halo through selective protection of natural ecosystems according to their values.
\end{abstract}

Keywords: Landscape; Anthropisation; Spatial dynamics; Remote sensing; Savanization halo; Lubumbashi

\section{Introduction}

During centuries, humans have profoundly altered the Earth's ecosystems through exploitation of natural resources and geographical area occupation [1]. This situation has been amplified since the beginning of the 20th century [2], and as consequence, landscapes are radically affected by anthropogenic disturbances [3]. One of the most critical human impacts is the removal of the original vegetation cover [4] followed, among others, by soil exposure to water and wind erosion [5], but also by a reduced availability of non-timber forest products, leading to persistent poverty and food insecurity [6]. This situation could be worse for Sub-Saharan African countries that already experience higher land use pressure than European countries [7]. As landscape constitutes a set of interacting ecosystems, its state largely affects that of soils, water and biodiversity, including human [8]. Consequently, spatio-temporal disturbances of natural landscapes are believed to be indicators for assessing ecosystems health [9].
In the Democratic Republic of Congo (Congo DR), population and urban growth associated with poor socio-economic conditions lead to activities that frequently alter landscape state [10]. In the Upper Katanga province, anthropogenic activities regularly reduce the remnant forest patches [11-14], particularly miombo woodland, the most extensive tropical woodland formation in Africa with particular ecological and economic importance $[15,16]$.

Around Lubumbashi (the most important city in the Upper Katanga province), the loss of natural vegetation is closely linked to agricultural development, charcoal production, city expansion and mining activities [16]. The visible consequences of these practices are, notably, the deforestation followed by forest fragmentation [17] leading to an anthropised landscape. For this reason, Lubumbashi city is surrounded by an area characterized by grassy and shrubby savanna, which reflects the anthropisation 
of forest ecosystem, often referred to as 'savanization halo' or 'deforestation radius' [16,18,19]. According to Useni et al. [20], the savanization halo around Lubumbashi led to an annual forest cover loss of nearly 6\% between 2002 and 2008 . However, local discrepencies may be observed, notably in areas close to sites of mining activities. Although Lubumbashi city represents a primary degradation nucleus of the surrounding landscapes $[17,18]$, the presence of a mining site may constitute a secondary nucleus [21] from which human activities might be diffused into natural ecosystems. This could lead not only to land saturation, but also to amplifications of conflicts between actors [22]. Therefore, there is an urgent need to preserve the rare natural ecosystems; however, to date, no clear approach is defined as to the way to intervene in the savanization halo where people largely depend on natural resources.

As anthropogenic pressure on natural landscapes, coupled with demographic change, will increase during the coming decades, this situation requires the development of adequate techniques to evaluate society and natural resources interactions [23]. Indeed, landscape dynamics generally modifies the ecological functioning that can be demonstrated by an assessment of their properties [24]. During the last decades, the ability to quantify landscape dynamics has been strongly enhanced by the use of remote sensing, Geographic Information System (GIS), and landscape ecology analysis tools [8, 25-27]. This is crucial in understanding the causes and consequences of landscape transformation [2], in order to develop effective tools for land-use planning and rational management of natural resources for sustainable development [22].

This study aims at appreciating, through land cover change analysis, the anthropisation of landscapes within the savanization halo between 2002 and 2017. It is verified whether the amplification of anthropogenic activities within the savanization halo, over time, could lead to complete landscape anthropisation and loss of ecosystem services [28].

\section{Materials and Methods}

\section{The study area}

This study focuses on the savanization halo around Lubumbashi city. Geographically, the study area $\left(11^{\circ} 21^{\prime}-11\right.$ $\circ 23 \mathrm{~S}$ and $27^{\circ} 26^{\prime}-27^{\circ} 46 \mathrm{E}$ ) covers $407.6 \mathrm{~km}^{2}$ and is located in the southern part Congo DR (Upper Katanga province). The outskirts of Lubumbashi city benefit from a Cw climate according to Köppen classification system, characterized by a dry season (May to September), a rainy season (November to March) and two transitional months (April and October) [29]. Nevertheless, Malaisse [30] has defined five seasons from phenological observations on vegetation: the cold dry season (May-July), the hot dry season (August-September), the early rainy season (October- November), the full rainy season (December-February) and the late rainy season (March-April). This pattern remains valid, although recent studies show a tendency to a later onset of rainfall and lower annual average rainfall [31]. The study area is crossed by a stream, the Kifumanshi River. During the second half of the last century, the average annual temperature was $20.1^{\circ} \mathrm{C}$ [6], though Kalombo [31] highlighted ongoing warming. The vegetation around Lubumbashi consists of wetland and remnant forest patches (miombo woodland or miombo; dense dry forest or muhulu; gallery forest or mushitu) in a matrix of savanna [32]. Ferralsols are the most dominant soil type in the study area [33]. As to population growth in the city, the annual growth rate is estimated at $4.6 \%$ based on statistics from 2000-2016 [34], while the national average urbanization rate is believed in the vicinity of $1.2 \%$ [35]. Mining activities are highly developed and give important socio-economic impulse to the study area. Within the savanization halo, shifting agriculture and traditional charcoal production are additional socio-economic activities of importance [36]. Furthermore, this area is prone to new housing demands without any consistent urban planning [37].

\section{Materials}

In order to detect land cover changes, the choice of adequate satellite images determines the success of the results to be obtained, as well as subsequent results interpretations [38]. The following cloud-free remotely sensed images, with a spatial resolution of $30 \mathrm{~m}$, were analysed: Landsat 7 Enhanced Thematic Mapper Plus (ETM+) images acquired on July 23, 2002, May 18, 2005, September 07, 2013 and Landsat 8 Operational Land Imager (OLI) acquired on August 25, 2017. All images were acquired during dry season in order to highlight the larger spectral differences between land cover classes, and to minimize the seasonal effect [39]. These images were analyzed using ENVI 4.5 and ArcGIS 10.0 software. Field survey data included ground control points and training zone, collected using Global Positioning Systems (GPS).

\section{Methods}

The Universal Transverse Mercator (UTM Zone 35 S), based on the WGS 84 reference ellipsoid (World Geodesic System), was used as coordinate system. As there are unsystematic errors in available remote sensing data, geometric correction was needed to reduce the errors [40]. The images used in this study were geometrically corrected using a Landsat OLI image from 2017 as a reference. Forty randomly distributed ground control points were used to rectify satellite images. Root mean square error was limited to 0.5 pixels, in accordance with recommendation for studies of land cover changes [41]. A false color composite was applied by combining the green bands with those that best discriminate vegetation (near infrared and red bands) [17]. An unsupervised classification led to sixteen land cover classes that were grouped based on their radiometric and thematic similarity. This grouping was supported by our knowledge gained from field visits and verification on old maps. However, a botanical inventory was also conducted to objectively separate shrubby savanna from miombo. Ninety training zones were recorded with a GPS in order to perform the supervised classification based on the maximum likelihood classifier [42] and integrated into a GIS to assess the accuracy of the supervised classification. 
Traditionally, classification accuracy refers to the comparison of two datasets, one based on analysis of remotely sensed data, and the other based on reference information [43]. Using field data and geographical features available on land cover maps, an accuracy assessment was performed, and the results were obtained in a confusion matrix $[9,40]$. The Kappa coefficient, which indicates how the classified data matches with the field reference data, was calculated; values exceeding 60\% are deemed acceptable [44].

A number of landscape metrics were employed to appreciate the changes in landscape attributes [2]: number of patches, class (total) area and total perimeter. Class (total) area depicts the relative abundance of each land cover type; number of patches is sensitive to landscape fragmentation; total perimeter is associated with landscape complexity [45]. Accordingly, these metrics make possible the assessment of landscape fragmentation, as well as the quantification of human impact [17]. The conversion between land cover classes was quantified using transition probability matrices, while spatial transformation processes were identified using a decision tree proposed by [46]. The input data for the decision tree include number of patches, class area and class perimeter between two dates, with the obtained variation allowing the identification of one of the following spatial transformation processes: aggregation, attrition, creation, deformation, dissection, enlargement, fragmentation, perforation, shift and shrinkage. In the case of anthropogenic landscape dynamics, the patches of natural classes will be characterized by attrition, deformation, dissection, fragmentation, perforation and/or shrinkage; the land cover associated to human activities display aggregation, creation, deformation, and enlargement and/or shift [12]. To differentiate fragmentation to dissection, $t$ obs (ratio of class area at the first date/class area at the second date) was calculated with a treshold value set at 0.5 [17]. A value of $t$ obs $<0.5$ is synonymous of fragmentation while a value of $t$ obs $\geq 0.5$ reveals dissection.

\section{Results}

\section{Supervised classification and mapping}

Five land cover classes have been selected, namely miombo (forest), savanna (grassland and schrub), wetland, waterbody (river, water reservoirs), and built-up-bare soil complex (builtup, bare soil, agricultural lands). The results of the confusion matrix showed overall accuracy values from around $91 \%$ to $96 \%$. The Kappa coefficient varied between $90 \%$ and $95 \%$ (Table 1). These values suggest that the supervised classification carried out was reliable and that land cover classes have been generally well discriminated (Figure 1).

Table 1: Accuracy of supervised classifications of Landsat images from 2002, 2007, 2013, and 2017 supported by the maximum likelihood algorithm.

\begin{tabular}{|c|c|c|c|c|}
\hline Indices (\%) & $\mathbf{2 0 0 2}$ & $\mathbf{2 0 0 7}$ & $\mathbf{2 0 1 3}$ & $\mathbf{2 0 1 7}$ \\
\hline Overall accuracy & 90.8 & 95.3 & 94.6 & 96.2 \\
\hline Kappa & 89.7 & 94.2 & 93.3 & 95.4 \\
\hline
\end{tabular}

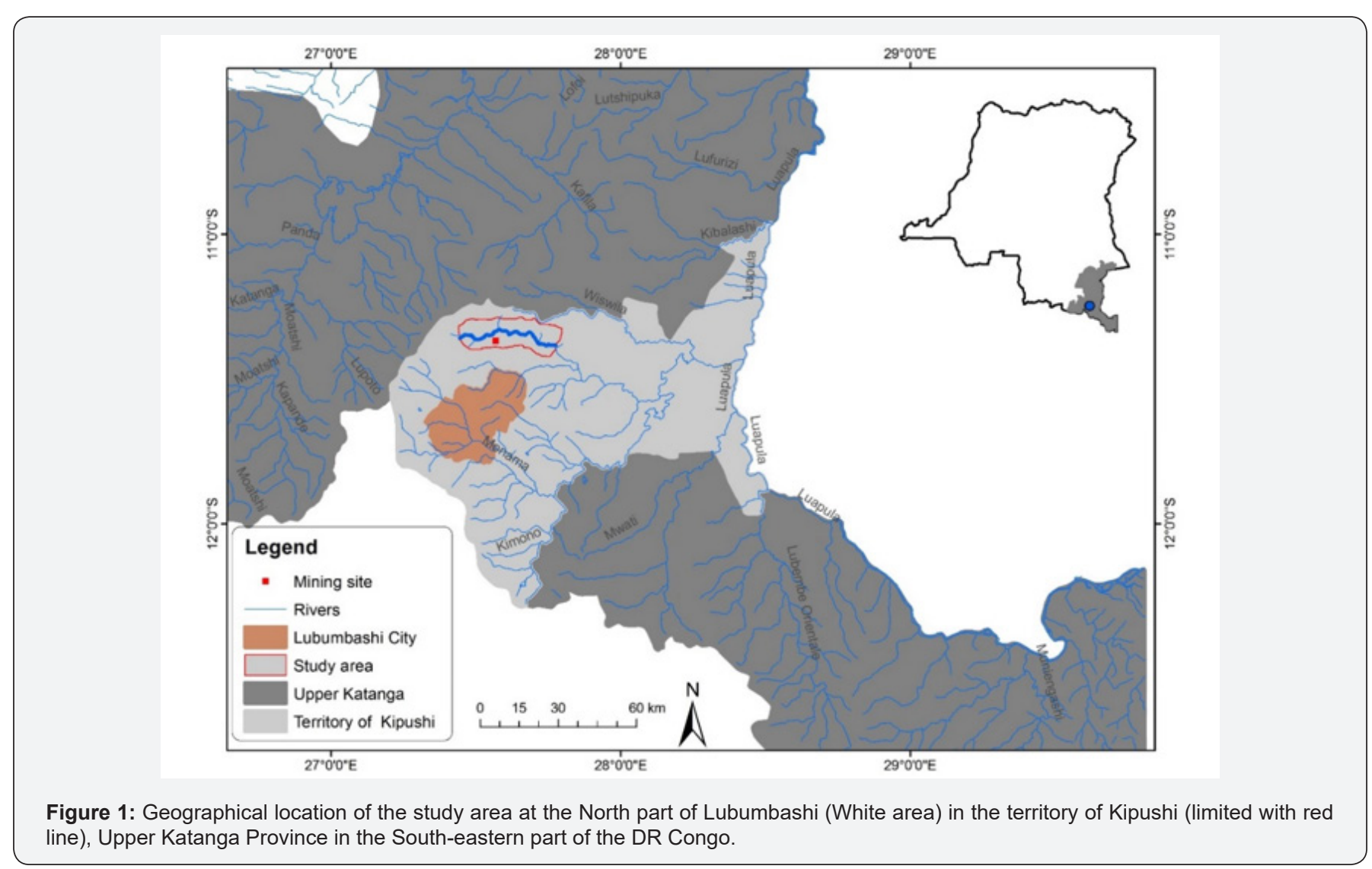


It was shown that the land cover pattern within the savanization halo has changed greatly from 2002 to 2017 (Figure 2). The visual analysis globally revealed that the identified land cover classes have recorded, in terms of spatio-temporal pattern changes, a regression trend (loss of area) and progressive trend (gain in area). The built-up-bare soil complex, waterbody and savanna have expanded rapidly across the landscape, resulting in miombo and wetland loss (Figure 2).

Table 2: Transition probability matrices describing the conversion of area between 2002-2007, 2007-2013 and 2013-2017 according to the supervised classification of Landsat images. Data are expressed in percent of land cover class in the landscape with 1 percent corresponding to $4.07 \mathrm{~km}^{2}$. The values in bold correspond to the proportion that remains unchanged for each land cover between two dates.

\begin{tabular}{|c|c|c|c|c|c|c|}
\hline $2007 / 2002$ & Miombo & Wetland & Savanna & Built-up-bare Soil Complex & Waterbody & Total \\
\hline Miombo & 58.4 & 0 & 0.6 & 0 & 0 & 59 \\
\hline Wetland & 0 & 12.2 & 2.1 & 1.7 & 0.5 & 16.5 \\
\hline Savanna & 0 & 0 & 15 & 3 & 0 & 18 \\
\hline $\begin{array}{l}\text { Built-up-bare soil } \\
\text { complex }\end{array}$ & 0 & 0 & 3.4 & 1.6 & 0 & 5 \\
\hline Waterbody & 0 & 0 & 0 & 0 & 1.5 & 1.5 \\
\hline Total & 58.4 & 12.2 & 21.1 & 6.3 & 2 & 100 \\
\hline $2007 / 2013$ & Miombo & Wetland & Savanna & Built-up-bare Soil Complex & Waterbody & Total \\
\hline Miombo & 29 & 0 & 29.4 & 0 & 0 & 58.4 \\
\hline Wetland & 0 & 3 & 0 & 4.4 & 4.8 & 12.2 \\
\hline Savanna & 0 & 0 & 13 & 6.1 & 2 & 21.1 \\
\hline $\begin{array}{l}\text { Built-up-bare soil } \\
\text { complex }\end{array}$ & 0 & 0 & 0 & 6.3 & 0 & 6.3 \\
\hline Waterbody & 0 & 0.4 & 0.4 & 0 & 1.2 & 2 \\
\hline Total & 29 & 3.4 & 42.8 & 16.8 & 8 & 100 \\
\hline $2013 / 2017$ & Miombo & Wetland & Savanna & Built-up-bare Soil Complex & Waterbody & Total \\
\hline Miombo & 19.7 & 0 & 8.4 & 0.9 & 0 & 29 \\
\hline Wetland & 0 & 2.3 & 0 & 0 & 1.1 & 3.4 \\
\hline Savanna & 0 & 0 & 42.3 & 0.5 & 0 & 42.8 \\
\hline $\begin{array}{l}\text { Built-up-bare soil } \\
\text { complex }\end{array}$ & 0 & 0 & 0 & 16.4 & 0.4 & 16.8 \\
\hline Waterbody & 0 & 0 & 0 & 0 & 8 & 8 \\
\hline Total & 19.7 & 2.3 & 50.7 & 17.8 & 9.5 & 100 \\
\hline
\end{tabular}

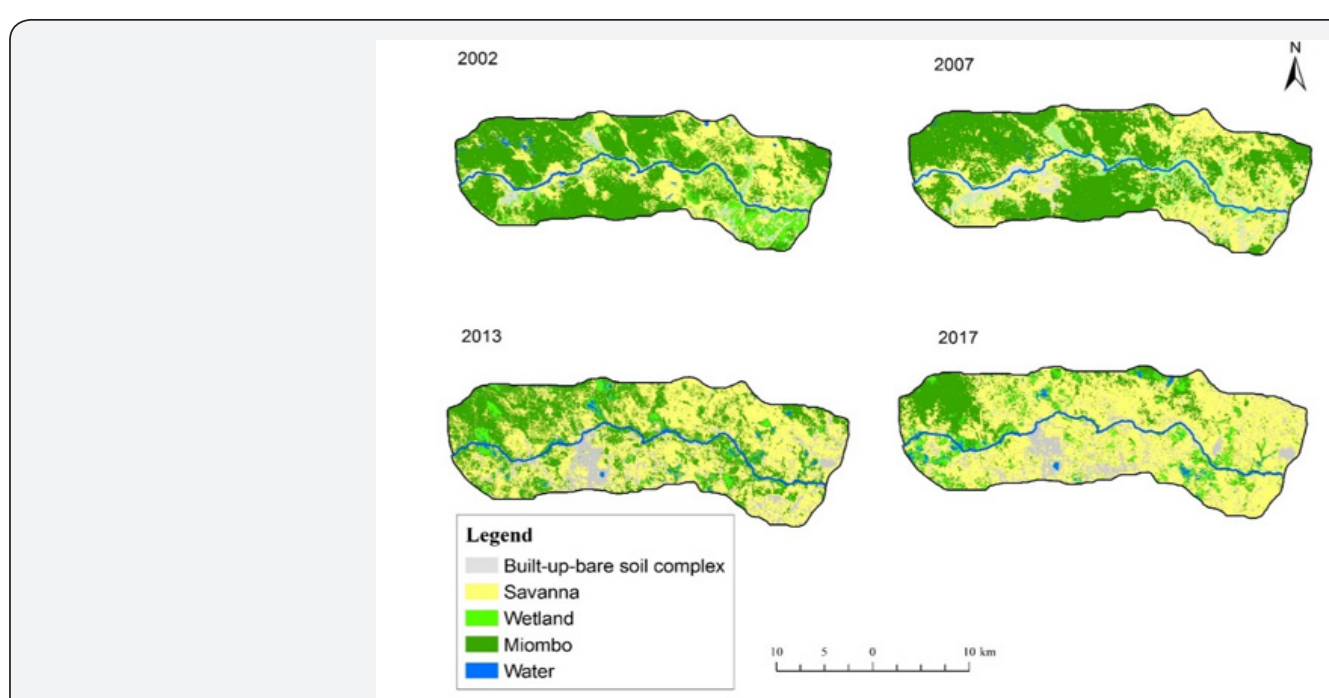

Figure 2: Land cover maps in 2002, 2007, 2013, 2017 based on the supervised classification of Landsat images supported by the maximum likelihood algorithm. 


\section{Conversion dynamics}

Over all periods investigated in this study (2002-2007, 2007-2013 and 2013-2017), miombo was the most stable land cover class between 2002-2013, while savanna was the most stable class from 2013 to 2017. Between 2002 and 2017, $38.4 \%$ of the landscape occupied by miombo evolved to savanna, $2.1 \%$ to wetland, $0.9 \%$ to built-up-bare soil complex while $0.4 \%$ of the landscape leaned towards flooded zones. A further landscape change was noticed from 2013 to 2017, consisting in the transformation of savanna into a new landscape matrix. No tendency to miombo regeneration was observed in all periods studied within the savanization halo. A relatively large area of the landscape previously occupied by savanna was either flooded between 2002 and 2017 (2\%) or invaded by built-up-bare soil complex (9.6\%). Over the same period of time, the wetland zone lost nearly $86 \%$ of its total area. In fact, $14.1 \%$ of the landscape occupied by wetland has evolved to built-up-bare soil complex $(6.1 \%)$ and waterbody (6.4\%). The wetland regeneration within the savanization halo was almost nil. The built-up-bare soil complex has increased significantly at the expense of savanna and wetland, but also at the miombo expense to a lesser extent.

In summary, within the savanization halo, three situations have been observed. Firstly, a progression of the anthropogenic classes (built-up-bare soil complex, savanna) at the expense of natural classes (miombo, wetland), but also the interconversion between anthropogenic classes. Secondly, a progression of waterbody at the expense of savanna and wetland. Finally, almost no regeneration of miombo and wetland classes (Table 2). Clearly, current result demonstrated that the amplification of anthropogenic pressure no longer allows the regeneration of natural ecosystems within the savanization halo around Lubumbashi city (Figure 3).

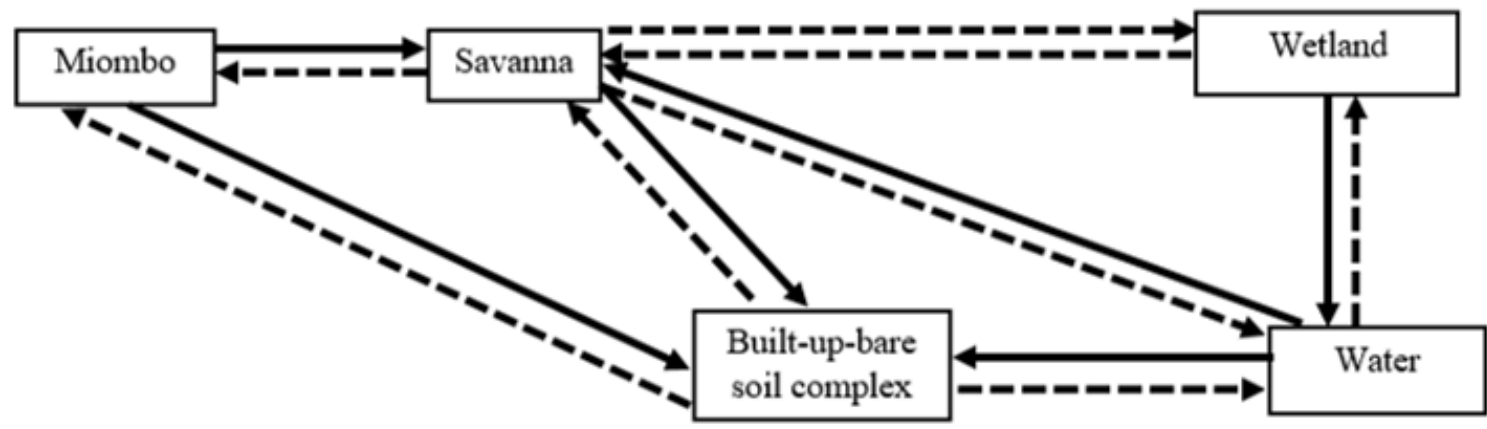

Figure 3: Illustration of the land cover conversion dynamics within the savanization halo around Lubumbashi city, a landscape overexploited for charcoal production, agriculture, urbanisation and mining. Solid arrows refer to effective land conversion between land cover classes. Dashed arrows refer to absence of conversion.

\section{Changes in landscape pattern and spatial transformation processes}

Table 3: Synthesis of landscape metrics characterizing the studied area in 2002, 2007, 2013 and 2013 . with $\mathrm{n}$ the number of patches and at the class (total) area $\left(\mathrm{km}^{2}\right)$. Total perimeter did not interfere with the identification of spatial transformation processes observed in the context of this study and its values are therefore not presented.

\begin{tabular}{|c|c|c|c|c|c|}
\hline & Miombo & Wetland & Savanna & Built-up-bare Soil Complex & Waterbody \\
\hline \multicolumn{6}{|c|}{2002} \\
\hline $\mathrm{n}$ & 2111 & 4224 & 5420 & 1423 & 603 \\
\hline$a_{t}$ & 240.1 & 67.2 & 73.3 & 20.4 & 6.1 \\
\hline \multicolumn{6}{|c|}{2007} \\
\hline $\mathrm{n}$ & 1753 & 3446 & 4393 & 1747 & 628 \\
\hline$a_{t}$ & 237.7 & 49.7 & 85.9 & 25.6 & 8.1 \\
\hline \multicolumn{6}{|c|}{2013} \\
\hline $\mathrm{n}$ & 3301 & 1468 & 1798 & 2230 & 924 \\
\hline$a_{t}$ & 118 & 13.8 & 174.2 & 68.4 & 32.6 \\
\hline \multicolumn{6}{|c|}{2017} \\
\hline $\mathrm{n}$ & 5889 & 1200 & 1842 & 2323 & 945 \\
\hline$a_{t}$ & 80.2 & 9.4 & 206.3 & 72.4 & 38.7 \\
\hline
\end{tabular}


Synoptic analysis of landscape metrics provided an overall summary of the savanization halo composition and configuration from 2002 to 2017. The number of patches and the total area of miombo decreased, suggesting patches attrition as spatial transformation process between 2002-2017. In parallel, the next period was characterized by a fragmentation and a dissection of miombo patches, respectively from 2007 to 2013 (t obs $0.44<0.5$ ) and 2013 to 2017 ( $t$ obs $0.98 \geq 0.5$ ), since the area decreased but number of patches increased. Between 2002-2017, wetland have experienced attrition as spatial transformation process marked by number of patches and total area decrease. The aggregation materialized by a decrease in number of patches accompanied by total area increase was characteristic of savanna between 20022013. From 2013 to 2017, the number of patches and the total area of the savanna class increased simultaneously, suggesting patches creation as the dominant spatial transformation process. Waterbody and built-up-bare soil complex creation was noted between 2002 and 2017 as the number of patches and their total area increased (Tables $3 \& 4$ ).

Table 4: Identification of spatial transformation processes within the savanization halo around Lubumbashi city 2002-2007, 2007-2013, 2013-2017 according to decision tree algorithm of Bogaert et al. [46].

\begin{tabular}{|c|c|c|c|}
\hline Land cover & $\mathbf{2 0 0 2 - 2 0 0 7}$ & $\mathbf{2 0 0 7 - 2 0 1 3}$ & $\mathbf{2 0 1 3 - 2 0 1 7}$ \\
\hline Miombo & Attrition & Fragmentation & Dissection \\
\hline Wetland & Attrition & Attrition & Attrition \\
\hline Savanna & Agregation & Agregation & Creation \\
\hline $\begin{array}{c}\text { Built-up-bare soil } \\
\text { complex }\end{array}$ & Creation & Creation & Creation \\
\hline Waterbody & Creation & Creation & Creation \\
\hline
\end{tabular}

\section{Discussion}

\section{Methodology}

The assessment of landscape characteristics results from the Pattern / process paradigm, which is the central hypothesis of landscape ecology according to which landscape structures influence the ecological processes and vice versa [45]. The verification of this central hypothesis within the savanization halo was based on the analysis of four Landsat images with different selection criteria (i.e. cloud saturation $(<10 \%)$ and seasonality) [39]. A supervised classification was conducted and generated a reliable level of accuracy.

Our study selected and tested landscape metrics referring to the number of patches, class area and total perimeter by land cover, which are considered as essential elements for landscape configuration characterization $[2,25,47,48]$. In addition, these metrics are considered as a strong indicator of human impact on landscape morphology [25,27]. In our study, few metrics were used because most are highly correlated [26]. The three metrics, coupled with decision tree [46] provide more information on spatial transformation processes underlying landscape dynamics and their potential drivers [2].

\section{Anthropization of natural ecosystems within the savanization halo around Lubumbashi city: spatial dynamics and drivers}

Around Lubumbashi city, rural people heavily rely on natural resources as source of wellbeing. Unsustainable exploitation of these resources is one of the root causes of deforestation [49], consequences of which result in very complex chain reactions [50]. Our results have revealed through transitions probabilities matrix that the savanization halo is dominated by savanization, urbanization, and deforestation. And concomitantly, the destruction of wetlands is leading to the flood of parts of the study area. These phenomena, caused by anthropogenic disturbances, have already been reported by other researchers in the same region $[16,18,19,51]$. In fact, direct drivers (i.e. slashand-burn farming, charcoal production, lumber exploitation, uncontrolled wildfires...), as well as indirect drivers (i.e.: current demographic explosion), underlie spatio-temporal dynamics within our study area. The savanization halo could possibly be considered as an ecologically eroded landscape with some intrinsic characteristic's loss (structure, composition, functionality and productivity). This could lead to recurrent fragility of ecosystems and living conditions [52].

Indeed, when agricultural land productivity decreases, populations are forced to migrate and explore new forest sites, where soils are deemed to be rich in nutrients that are essential to crops development [15]. Forkuor \& Cofie [53] findings around Freetown (Sierra Leone) showed that about 14\% of evergreen forest have been converted to agricultural land. Our results show that forest and wetland regression rate might have been underestimated $[18,20]$. This may result from spatial extent differences between study area, showing the importance of spatial scale in landscape ecology [2,54]. In certain areas around the city, spaces allocated for horticultural activities are such concentrated along wetlands that their expansion could explain, at least partly, the regression of wetland acreage. In particular, the disappearance of some wetland patches may be accompanied by lateralization resulting from the combined effects of high temperatures and abundant amounts of water on bare ferralitic soils [33]. Our results corroborate this trend and [55] confirmed the frequent flooding in neighborhoods where built-up have invaded wetland in Lubumbashi city. In addition, bare soil, where rainwater often remain stagnating, favors in some areas the proliferation of Anopheles mosquito larvae transmitting malaria [56]. The increase of waterbody area could also be in relation with the creation of fish ponds. In fact, owing to the current context of socio-economic crisis witnessed in Lubumbashi city and surrounding area, crop and animal production stands as a rescue activity for up to one third of households [57].

Our results reflect the general landscape dynamics tendency within the savanization halo, where peri-urbanisation linked with a rapid population growth induces an anarchic expansion of the city [58]. Lubumbashi city and its urban dwellers put a 
big pressure on surrounding ecosystems [18]. In fact, there is a direct correlation between population growth and the demand for land, food and energy [10]. In addition, Kabulu et al. [59] reveal that the remnant forest patches in the Upper Katanga province are facing extreme pressure for charcoal production to meet the ever-increasing energy needs of the Lubumbashi city. Surprisingly, small motorized equipment, such as chainsaws, are the most commonly used tools for cutting trees which then will allow charcoal production. For this reason, Kabulu et al. [59] concluded that charcoal production is one of the main causes of forest fragmentation and degradation in the Upper Katanga province. Bangirinama et al. [60] also showed that the use of woody charcoal as energy source for urban population is a serious problem for forest cover conservation in Burundi. On another hand, the proximity of mining site could favor landscape anthropization due to economic opportunities for both urban and rural population [21].

Although the landscape is primarily composed by anthropogenic land cover classes, some forest patches still remain present and are potentially threatened by the lack of rigorous land use planning strategies [16]. Another manifestation of landscape anthropization and miombo forest degradation is the significant regression of trees diameter over time, which greatly affects ecosystem regeneration and long-term ecosystem services supply (i.e.: charcoal production) [12]. By reducing the patches area, simplifying their morphology and increasing their spatial isolation [46], the fragmentation of natural ecosystem stains has completely altered the spatial configuration of the landscape in the savanization halo and can surely alter the evolution of biological diversity. Yet, many studies have revealed the importance of miombo species for food and other social needs of local populations $[12,16,51,61]$.

\section{Conclusion}

The use of landscape ecology approach associated with remote sensing and GIS were useful for landscape spatial pattern change evaluation within the savanization halo. Current results show that the study area is facing a rapid and consistent spatiotemporal dynamic. Due to cutting wood for charcoal production that led to savanization, and the expansion of the built-up-bare soil complex, the miombo ecosystem is significantly decreasing from 2002 to 2017 . Within the study area, wetland destruction has given way to bare soils that are regularly being flooded. The aforementioned changes were supported by five spatial transformation processes (i.e., dissection, fragmentation, attrition, creation and aggregation). Human activities have significantly altered natural ecosystems within the savanization halo, affecting their resilience. Although we already highlighted some processes and drivers linked with this landscape transformation, a need still subsists for better understanding the socio-environmental impact of charring, and agricultural practices for long term landscape sustainability.

\section{References}

1. Millenium Ecosystem Assessment (2005) Ecosystems and Human Well-being: Synthesis. Island Press, Washington, DC, USA.

2. Bogaert J, Mahamane A (2005) Ecologie du paysage: cibler la configuration et l'échelle spatiale. Annales des Sciences Agronomiques du Bénin 7(1): 39-68.

3. Wu JG (2013) Key concepts and research topics in Landscape ecology revisited: 30 years after the Allerton Park workshop. Landscape Ecology 28(1): 1-11.

4. Bogaert J, Bamba I, Kabulu DJP, Koffi KJ, De Cannière C, et al. (2008) Fragmentation of forest landscapes in central Africa: causes, consequences and management. In: Lafortezza R, Chen R, Sanesi G, Crow Th R (Eds.), Patterns and Processes in Forest Landscapes: Multiple Use and Sustainable Management. Verlag, Springer, New York, USA, pp. 67-87.

5. Vranken I, Amisi MY, Munyemba KF, Bamba I, Veroustraete F, et al. (2013) The Spatial Footprint of the Non-ferrous Mining Industry in Lubumbashi. Tropicultura 31(1): 22-29.

6. Malaisse F (2010) How to live and survive in Zambezian open foret (Miombo ecoregion). Les Presses Agronomiques de Gembloux (Belgique), p. 422

7. Kestemont B, Frendo L, Zaccaï E (2011) Indicators of development on environment: a comparison of Africa and Europe. Ecological Indicators 11(3): 848-856.

8. Forman RTT, Godron M (1986) Landscape ecology. John Wiley \& Sons, New York, USA, p. 640.

9. Mama A, Sinsin B, De Cannière C, Bogaert J (2013) Anthropisation et dynamique des paysages en zones soudanienne au Nord du Bénin. Tropicultura 31(1): 78-88.

10. Bamba I (2010) Anthropisation et dynamique spatio-temporelle de paysages forestiers en République Démocratique du Congo. Université Libre de Bruxelles (Brussels, Belgium): PhD Thesis, p. 181.

11. Kabulu DJP, Bamba I, Munyemba KF, Defourny P, Vancutsem C, et al. (2008) Analyse de la structure spatiale des forêts au Katanga. Annales de la Faculté des Sciences Agronomiques de l'Université de Lubumbashi 1(2): 12-18.

12. Barima YSS, Kabulu DJP, Alongo S, Ndayishimiye J, Bomolo O, et al (2011) Deforestation in central and West Africa: landscape dynamics, anthropogenic effects and ecological consequences. In Daniels JA (Ed.) Advances in environmental research. Vol 7, Nova Science Publishers, Hauppauge, pp. 95- 120.

13. Potapov PV, Turubanova SA, Hansen MC, Adusei B, Broich M, et al (2012) Quantifying forest cover loss in Democratic Republic of the Congo, 2000-2010, with Landsat ETM+ data. Remote Sensing of Environment 122: 106-116.

14. Dupin L, Nkono C, Burlet C, Muhashi F, Vanbrabant Y (2013) Land Cover Fragmentation Using Multi-Temporal Remote Sensing on Major Mine Sites in Southern Katanga (Democratic Republic of Congo). Advances in Remote Sensing 2(2): 127-139.

15. Cabala KS, Useni SY, Sambieni KR, Bogaert J, Munyemba KF (2017) Dynamique des écosystèmes forestiers de l'Arc Cuprifère Katangais en République Démocratique du Congo. I. Causes, Transformations spatiales et ampleur. Tropicultura 35(3): 192-202.

16. Useni SY, Malaisse F, Cabala KS, Munyemba KF, Bogaert J (2017a) Le rayon de déforestation autour de la ville de Lubumbashi (Haut Katanga, R.D. Congo) : synthèse. Tropicultura 35(3): 215-221.

17. Barima YSS, Barbier N, Bamba I, Traoré D, Lejoly J, et al. (2009) Dynamique paysagère en milieu de transition forêt-savane ivoiriènne. Bois et Forêts des Tropiques 299(1): 15-25. 
18. Munyemba KF, Bogaert J (2014) Anthropisation et dynamique spatiotemporelle de l'occupation du sol dans la région de Lubumbashi entre 1956 et 2009. Revue électronique de l’Université de Lubumbashi 1: 3-23.

19. Cabala KS, Useni SY, Munyemba KF, Bogaert J (2018) Activités anthropiques et dynamique spatiotemporelle de la forêt claire dans la Plaine de Lubumbashi. In : Bogaert J, Colinet G, Mahy G (Eds.), Anthropisation des paysages Katangais. Gembloux, Belgique : Les Presses Universitaires de Liège, Belgium, pp. 253-266.

20. Useni SY, André M, Mahy G, Cabala KS, Malaisse F, et al. (2018a) Interprétation paysagère du processus d'urbanisation à Lubumbashi: dynamique de la structure spatiale et suivi des indicateurs écologiques entre 2002 et 2008. In Bogaert J, Colinet G, Mahy G (Eds.) Anthropisation des paysages Katangais. Gembloux, Belgique : Les Presses Universitaires de Liège, Belgium, pp. 281-296.

21. Weerts A (2015) Sites miniers en République Démocratique du Congo : conflits et développement autour d'un espace hybride. In : Bogaert J, Halleux JM (Eds.), Territoires périurbains : développement, enjeux et perspectives dans les pays du sud. Gembloux, Belgique : Les presses Agronomiques de Gembloux, Belgium, pp. 75-81.

22. Sadda AS, Diouf A, Lawali S, Ouedraogo M, Bogaert J, et al. (2016) Pression anthropique et dynamique paysagère en zone rurale semi-aride : cas de la commune de Tibiri, région de Maradi (Niger) Tropicultura 34(2): 127-139.

23. Bogaert J, Farina A, Ceulemans R (2005) Entropy increase of fragmented habitats: A sign of human impact? Ecological Indicators 5(3): 207-212.

24. Bogaert J, André M (2013) L'écologie du paysage: une discipline unificatrice. Tropicultura 31(1): 1-2.

25. O’Neill RV, Krummel JR, Gardener RH, Sugihara G, Jacksin B, et al (1988) Indices of landscape pattern. Landscape Ecology 1(3): 153-162.

26. Li H, Wu J (2004) Use and misuse of landscape indices. Landscape Ecology 19(4): 389-399.

27. Bogaert J, Vranken I, André M (2014) Anthropogenic effects in landscapes: historical context and spatial pattern. In: Hong SK, Bogaert J, Min Q (Eds.), Biocultural landscapes. Diversity, functions and values. Dordrecht, Springer, The Netherlands, pp. 89-112.

28. Gillet P, Vermeulen C, Doucet JL, Codina E, Lehnebach C, et al. (2016) What are the impacts of deforestation on the harvest of non-timber forest products in Central Africa? Forests 7(5): 106.

29. Assani AA (1999) Analyse de la variabilité temporelle des précipitations (1916-1996) à Lubumbashi (Congo-Kinshasa) en relation avec certains indicateurs de la circulation atmosphériques (oscillation austral) et océaniques (El Niño/La Niña). Sécheresse 10(4): 245-252.

30. Malaisse F (1974) Phenology of Zambezian wodland area with emphasis on the Miombo ecosystem. In: Lieth (Ed.), Phenology and seasonality modeling. Spring Verlag, Berlin-Heidelberg, New York: Ecol. Stud 8: 269-286.

31. Kalombo KD (2016) Evaluation des éléments du climat en R.D.C. Editions Universitaires Européennes, Saarbrücken (Allemagne), p. 220

32. Malaisse F (1979) The Miombo ecosystem. In: UNESCO, UNEP and FAO (Compilers) (Eds.), Tropical Forest Ecosystems. Paris (France) 14: pp 589-606.

33. Ngongo LM, Van Ranst E, Baert G, Kasongo LE, Verdoodt A, et al. (2009) Guide des Sols en République Démocratique du Congo, Tome I: Etude et Gestion. Don Bosco, Lubumbashi, Democratic Republic of the Congo.

34. United Nations (2016) The World's Cities in 2016. Department of Economic and Social Affairs, Population Division, Data Booklet (ST/ ESA/ SER.A/392).
35. United Nations (2014) World Urbanization Prospects: The 2014 Revision. Department of Economic and Social Affairs, Population Division, Highlights (ST/ESA/SER.A/352).

36. Useni SY, Cabala KS, Nkuku KC, Amisi MY, Malaisse F, et al. (2017b) Vingt-cinq ans de monitoring de la dynamique spatiale des espaces verts en réponse à l'urbanisation dans les communes de la ville de Lubumbashi (Haut-Katanga, R.D. Congo). Tropicultura 35(4): 300-311.

37. Groupe Huit (2009) Elaboration du plan urbain de référence de Lubumbashi. Rapport final Groupe Huit, BEAU, Ministère des ITR, RD Congo, p. 62.

38. Saura S (2004) Effects of remote sensor spatial resolution and data aggregation on selected fragmentation indices. Landscape Ecology $19(2): 197-209$.

39. Song C, Woodcock CE, Seto KC, Lenney MP, Macomber SA (2001) Classification and Change Detection Using Landsat TM Data: When an How to Correct Atmospheric Effects? Remote Sensing of Environment 75(2): 230-244.

40. Byomkesh T, Nakagoshi N, Dewan AM (2012) Urbanization and green space dynamics in Greater Dhaka, Bangladesh. Landscape and Ecological Engineering 8(1): 45-58.

41. Mas JF (2000). Une revue des méthodes et des techniques de télédétection du changement. Canadian Journal of Remote Sensing 26(4): 349-362.

42. Caloz R, Collet C (2001) Précis de télédétection: traitements numériques d'images de télédétection. Volume 3, Québec, Presses de l’Université de Québec, Canada, p. 386.

43. Congalton RG (1991) A review of assessing the accuracy of classifications of remotely sensed data. Remote Sensing of Environment 37(1): 35-46.

44. Landis JR, Koch GG (1977) The measurement of observer agreement for categorical data. Biometrics 33(1): 159-174.

45.Zhou X, Wang YC (2011) Spatial-temporal dynamics of urban green space in response to rapid urbanization and greening policies. Landscape and Urban Planning 100(3): 268-277.

46. Bogaert J, Ceulemans R, Salvador-Van Eysenrode D (2004) Decision tree algorithm for detection of spatial processes in landscape transformation. Environ Manage 33(1): 62-73.

47. Riitters KH, O’Neill RV, Hunsaker CT, Wickham JD, Yankee DH, et al. (1995) A factor analysis of landscape pattern and structure indices. Landscape Ecology 10(1): 23-39.

48. McGarigal K (2015) FRAGSTATS help.

49. Vermeulen C, Dubiez E, Proces P, Mukumary SD, Yamba Yamba T, et al. (2011) Enjeux fonciers, exploitation des ressources naturelles et forêts des communautés locales en périphérie de Kinshasa, RDC. Biotechnologie, Agronomie, Société et Environnement 15(4) : 535-544.

50. Bogaert J, Barima YSS, Ji J, Jiang H, Bamba I, et al. (2011) A Methodological Framework to Quantify Anthropogenic Effects on Landscape Patterns. In: Kong SK, Wu J, Kim JE, Nakagoshi N (Eds.), Landscape ecology in Asian cultures. Springer, Verlag, New York, USA, pp. 141-167.

51. Mwitwa J, German L, Muimba-Kankolongo A, Puntondewo A (2012) Governance and sustainability challenges in landscape shaped by mining: Mining-forestry linkages and impacts in the copper belt of Zambia and the DR Congo. Forest Policy and Economics 25: 19-30.

52. Alongo S, Visser M, Drouet T, Kombele F, Colinet G, et al. (2013) Effets de la fragmentation des forêts par l'agriculture itinérante sur la dégradation de quelques propriétés physiques d'un Ferralsol échantillonné à Yangambi, RD Congo. Tropicultura 31(1): 36-43.

53. Forkuor G, Cofie O (2011) Dynamics of land-use and land-cover change in Freetown, Sierra Leone and its effects on urban and peri- 
urban agriculture-a remote sensing approach. International Journal of Remote Sensing 32(4): 1017-1037.

54. Wu JG (2004) Effects of changing scale in landscape pattern analysis: scaling relations. Landscape Ecology 19(2): 125-138.

55. Muteb MC (2013) Vulnérabilités et stratégies d'adaptation aux risques d'inondations dans le contexte urbain : cas des quartiers construits dans les zones inondables à Lubumbashi. Mémoire de master Complémentaire en Planification et Gestion Urbaine, Université de Lubumbashi, Democratic Republic of the Congo.

56. Patz JA, Daszak P, Tabor GM, Aguirre AA, Pearl M, et al. (2004) Unhealthy landscapes: policy recommendations on land use change and infectious disease emergence. Environ Health Perspect 112(10):1092.

57. Nkuku KC, Rémon M (2006) Stratégies de survie à Lubumbashi (R-D Congo). Enquête sur 14000 ménages urbains. Paris, France: Archive congolaise, l'Harmattan.

58. Useni SY, Cabala KS, Halleux JM, Bogaert J, Munyemba KF (2018b) Caractérisation de la croissance spatiale urbaine de la ville de
Lubumbashi (Haut-Katanga, R.D. Congo) entre 1989 et 2014. Tropicultura 36(1): 99-108.

59. Kabulu DJP, Vranken I, Bastin JF, Malaisse F, Nyembwe S, et al. (2018) Approvisionnement en charbon de bois des ménages lushois : quantités, alternatives et conséquences. In : Bogaert J, Colinet G, Mahy G (Eds.), Anthropisation des paysages Katangais. Gembloux, Belgique : Les Presses Universitaires de Liège, Belgium, pp. 297-311.

60. Bangirinama F, Nzitwanayo B, Hakizimana P (2016) Utilisation du charbon de bois comme principale source d'énergie de la population urbaine : un sérieux problème pour la conservation du couvert forestier au Burundi. Bois et Forêts des Tropiques 328(2): 45-53.

61. Hick A, Maud H, Tshibungu NA, Mahy G (2018) La place de l'arbre dans les systèmes agricoles par les populations locales. In: Bogaert J, Colinet G, Mahy G (Eds.), Anthropisation des paysages Katangais. Gembloux, Belgique : Les Presses Universitaires de Liège, Belgium, pp. 111-123.

Your next submission with Juniper Publishers
will reach you the below assets
- Quality Editorial service
- Swift Peer Review
- Reprints availability
- E-prints Service
- Manuscript Podcast for convenient understanding
- Global attainment for your research
- Manuscript accessibility in different formats
( Pdf, E-pub, Full Text, Audio)
- Unceasing customer service
Track the below URL for one-step submission
https://juniperpublishers.com/online-submission.php

